\title{
A New Species of Predaceous Midge of the Genus Monohelea Kieffer from Mexico (Diptera: Ceratopogonidae)
}

\author{
Maria Luiza Felippe-Bauer/ ${ }^{+}$, Heron Huerta*, Sergio Ibañez Bernal** \\ Laboratório de Diptera, Departamento de Entomologia, Instituto Oswaldo Cruz, Av. Brasil 4365, 21045-900 \\ Rio de Janeiro, RJ, Brasil *Departamento de Entomología, Instituto Nacional de Diagnóstico y \\ Referencia Epidemiológicos, Mexico, D.F. ** Departamento de Entomologia, Instituto de Ecologia, \\ Veracruz, México
}

\begin{abstract}
A description and illustrations of Monohelea maya, new species, based on male and female characteristics are provided. The specimens were collected in the special biosphere Reserves of Ria Lagartos and Ria Celestun, Yucatan State, Mexico.
\end{abstract}

Key words: Diptera - Ceratopogonidae - neotropical predaceous midge - Monohelea maya sp.n. - Mexico

Monohelea Kieffer is one of the genera of predaceous midges that is poorly known in Mexico. Only Monohelea maculipennis (Coquillett) has been previously reported in this country (Huerta 1996). During a recent study carried out in two special reserves in the State of Yucatan (Ria Lagartos and Ria Celestun), adults of an undescribed species of Monohelea were collected.

The purpose of this work is to describe and illustrate this new species, based on slide mounted specimens. All measurements are in micrometers, except those of the wings which are in millimeters. The general terminology is that employed in papers on Monohelea by Wirth and Williams (1964) for North American species, Lane and Wirth (1964) for Neotropical species, and Ratanaworabhan and Wirth (1972) for Oriental species. World lists of the species of Monohelea is found in Wirth and Grogan (1988) and Borkent and Wirth (1997).

Monohelea maya, new species

Felippe-Bauer, Huerta \& Ibáñez-Bernal

(Figs 1-12)

Type locality: Reserve Ria Lagartos, Yucatan, Mexico.

Female - Head: eyes (Fig. 3) bare, narrowly contiguous. Antenna (Fig. 4) pale brown; pedicel and

\footnotetext{
${ }^{+}$Corresponding author. Fax: + 55-21-290.9339. E-mail: mlfbauer@gene.dbbm.fiocruz.br

This work is the third contribution of the project "Díptera hematofagos y taxa relacionados de dos áreas protegidas del Estado de Yucatán, México. INDRE-CONABIO: GQ11".

Received 2 December 1999

Accepted 28 June 2000
}

first flagellomere brown; flagellomeres cylindrical, with lengths 69- 48- 51- 53- 56- 59- 59- 5975- 75- 83- 85- 96; antennal ratio 0.91 (0.88-0.95, $\mathrm{n}=11$ ). Palpus (Fig. 6) uniformly pale brown; combined length of segments 3-5 slightly shorter than proboscis; lengths of segments 21-37-43-2953; 3rd segment elongated with small shallow, rounded sensory organ on mid portion; palpal ratio $2.1(1.9-2.2, \mathrm{n}=11)$. Mandible with 8 teeth.

Thorax: without definite pattern on slide mounted specimens. Legs (Fig. 5) unarmed, yellow; coxae brown; hind femur with proximal $1 / 3$ and apical portion dark brown, mid portion with a narrow brown band; apices of tibiae dark brown; hind tibiae with additional dark brown band on proximal $1 / 5$ and smaller brown spot on mid portion; hind tibial comb with 7 bristles; trochanters, femora, tibiae of fore, mid, hind legs with lengths 96- 512- 491, 96555- 523, 107-661-640. Tarsi: pale, pilose; tarsomere I of hind leg with one row of ventral palisade setae, with one basal and one apical spine on fore and hind legs; with 2 basal and 2 apical spines on mid leg; tarsomeres 2-4 of fore, mid, hind legs with number of apical spines as follows: 1-12, 2-2-2, 1-1-2, basal spines absent; fore, mid, hind tarsomeres with lengths 288- 128- 85- 64- 107, 309128- 75- 53- 96, 384- 171- 107- 85- 75; fore, mid, hind tarsal ratios $2.3(2.2-2.8, \mathrm{n}=11), 2.4(2.3-$ 2.7,n=11), $2.2(2.1-2.4, \mathrm{n}=11)$; fore, mid claws, paired, equal-sized, about 0.7 times as long as 5th tarsomere; hind claw simple, 1.5 times as long as 5th tarsomere. Wing (Fig. 1) with irregular dark areas, spots of typical hieroglyphic pattern; macrotrichia restricted to veins costa, radius, Rl and distal portion of vein M1, cells $\mathrm{r} 5$ and $\mathrm{m} 1$; microtrichia absent; 2 nd radial cell nearly 2.1 times longer than $1 \mathrm{st}$; wing length $1.24(1.15-1.32, \mathrm{n}=5)$ $\mathrm{mm}$, width $0.46(0.42-0.49, \mathrm{n}=5) \mathrm{mm}$; costal ratio $0.80(0.78-0.82, n=5)$. Halter pale. 


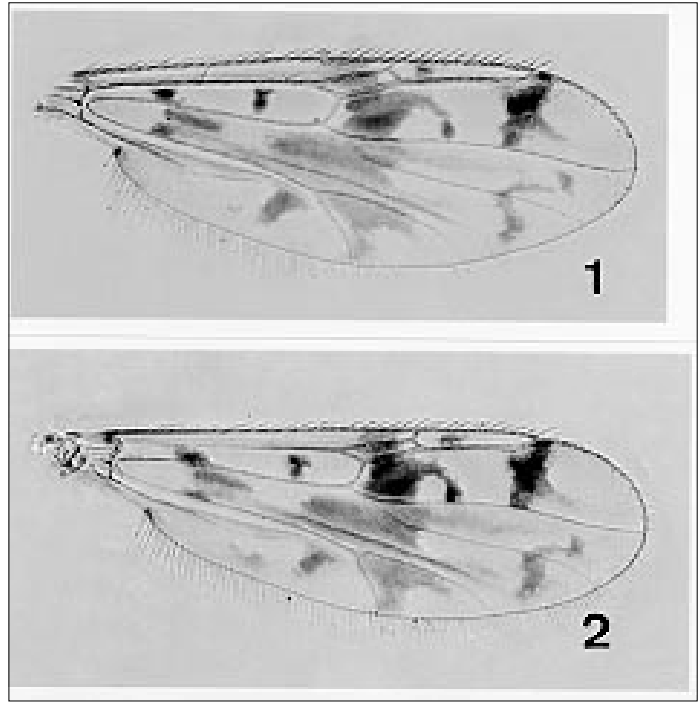

Wing photographs of Monohelea maya sp.n. Fig. 1: female. Fig. 2: male.

Abdomen (Fig. 10): pale brown; sternite VIII without pigmented areas, with a deep median excavation contoured by pale area; sternite IX with median portion as 2 pigmented parentheses separated by a median triangular plate; sternite $\mathrm{X}$, triangular, with 4 setae, the posterior 2 longer than the anterior 2. Spermathecae (Fig. 8) very unequal, measuring 85 by 64 and 43 by 37, the larger one with short sclerotized neck, measuring 11; the smaller with very long slender neck.

Male: similar to female with the following notable sexual differences. Wing length 0.95 (0.84-1.05, $\mathrm{n}=10) \mathrm{mm}$; width $0.35(0.32-0.38, \mathrm{n}=10) \mathrm{mm}$. Antenna pale brown with pedicel, flagellomeres 1, 1113 darker; flagellomeres 2-9 somewhat barrelshaped, 10 nearly twice as long as wide, 11-13 elongate; lengths of flagellomeres 115- 37- 37- 37- 3232- 32- 29- 27- 37- 101- 101- 109; antennal ratio (9-13/1-8) 0.92. Palpus pale brown; segments 3-5 with lengths 37-27-48; palpal ratio 2.1. Legs pattern as in female; trochanters, femora, tibiae of fore, mid, hind legs with lengths 85- 395- 363, 85- 437395, 96- 501- 469. Fore, mid, hind tarsomeres with lengths 213- 96- 75- 53- 64, 245- 96- 75- 53- 53, 265- 139- 96- 64- 64; fore, mid, hind tarsal ratios 2.2 (2.0-2.4, n=10), 2.4 (2.3-2.5, $\mathrm{n}=10), 1.8$ (1.8$1.9, \mathrm{n}=10)$; claws small, paired, equal-sized, 0.5 times as long as 5th tarsomeres. Wing (Fig. 2) with characteristic pattern as in female; costal ratio 0.75 (0.73-0.76, $\mathrm{n}=10)$.

Genitalia (Figs 9, 11-12): sternite IX spiculate except on basal portion, posterior margin with a short, convex, median lobe with 4 long setae; tergite IX tapering, with pair of apicolateral processes, each with 3 setae. Gonocoxite 1.7 (1.5-1.9, n=9) times longer than basal width; gonostylus curved distally, $0.69(0.64-0.75, \mathrm{n}=9)$ times as long as gonocoxite, moderately pilose on basal 3/4. Aedeagus (Fig.11): triangular, composed of 2 pointed ventral plates, each with only delicately sclerotized apical projection, without sclerotized dorsal structure; aedeagus as long as basal breadth. Parameres (Fig. 12) nearly $1.4(1.2-1.5, n=9)$ times longer than aedeagus; narrowly fused at midlength; each with broad base; stem straight, gradually tapering to blunt apex, without median process.

Distribution: Mexico, Yucatan.

Type: holotype male, Loc. Ojo de Agua, Res. Ria Lagartos, Yucatan, MEXICO, 31-VIII-1995, Navarro C., Paz R. Huerta H. colls., in Petén veg., malaise trap (CONABIO 97.03648) (21 ${ }^{\circ} 34^{\prime} 48^{\prime \prime} \mathrm{N}$ $88^{\circ} 09^{\prime} 46^{\prime}$ 'W). Allotype female, $10 \mathrm{~km}$ E. of highway San Felipe-Las Coloradas, Ria Lagartos, Yucatan, MEXICO, 04-IV-1997, IBS, MMCL, PMS, H.H. colls.; in Petén veg., malaise trap. Paratypes, 25 males, 30 females, as follows: 22 males, 19 females same data as allotype ( 3 females, 1 male CONABIO 95.0309-95.0312); 2 males, 6 females, $10 \mathrm{~km}$ E. of highway Ria Lagartos-Las Coloradas, Loc. Petén Tucha, Ria Lagartos, Yucatan, MEXICO, 04-IV-1997, IBS, MMCL, MSP colls., in Petén veg., malaise trap (21 ${ }^{\circ} 35^{\prime} 46^{\prime \prime}$

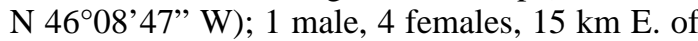
highway Celestún-Kinchil, Rancho Loma Bonita, Celestún, Yucatan, MEXICO, 09-IV-1997, IBS, HJH, MML, MSP colls., in Petén veg., malaise trap (2050'42” N 90 16'17' W); 1 female, Loc. Tucha, Res. Ria Lagartos, Yucatan, MEXICO, 01-IX1995, Navarro C., Paz R., Huerta H. colls., in Petén veg., malaise trap (CONABIO 97.03652) [Holotype (no. 278), allotype (no. 279) and 23 paratypes (no. 280-302) deposited in Instituto Oswaldo Cruz, Rio de Janeiro, Brazil; 12 paratypes, same data as allotype: 3 males, 3 females deposited in Depto. de Epidemiologia, Faculdade de Saúde Pública, Universidade de São Paulo, São Paulo, Brazil and 3 males, 3 females deposited in Museo de La Plata, La Plata, Argentine; 20 paratypes, including 5 specimens coded with CONABIO (95.030995.0312, 97.03652) deposited in the Arthropod Collection of Medical Importance of the Instituto Nacional de Diagnóstico y Referencia Epidemiológicos (INDRE), Mexico].

Etymology: the name maya, refers to the native Indians found in the Yucatan peninsula.

Discussion: M. maya shares a similar pattern of wing and leg pigmentation with the neotropical species M. mayeri Ortiz. However, M. maya differs from $M$. mayeri by the shape of the paramere which is simple, straight and without apical tooth. 

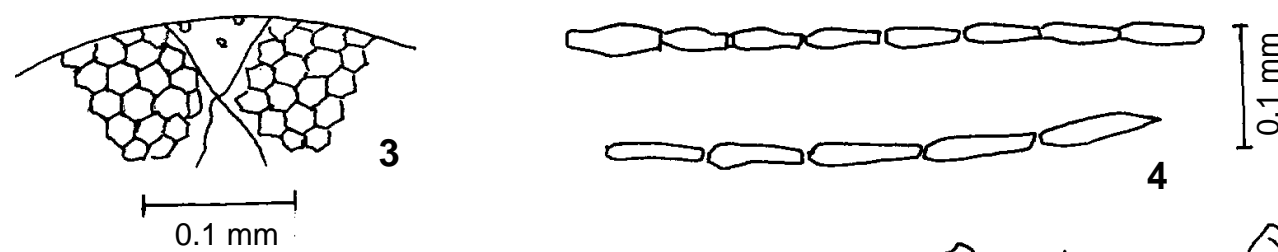

\section{$E$
$\varepsilon$
$\sigma$}
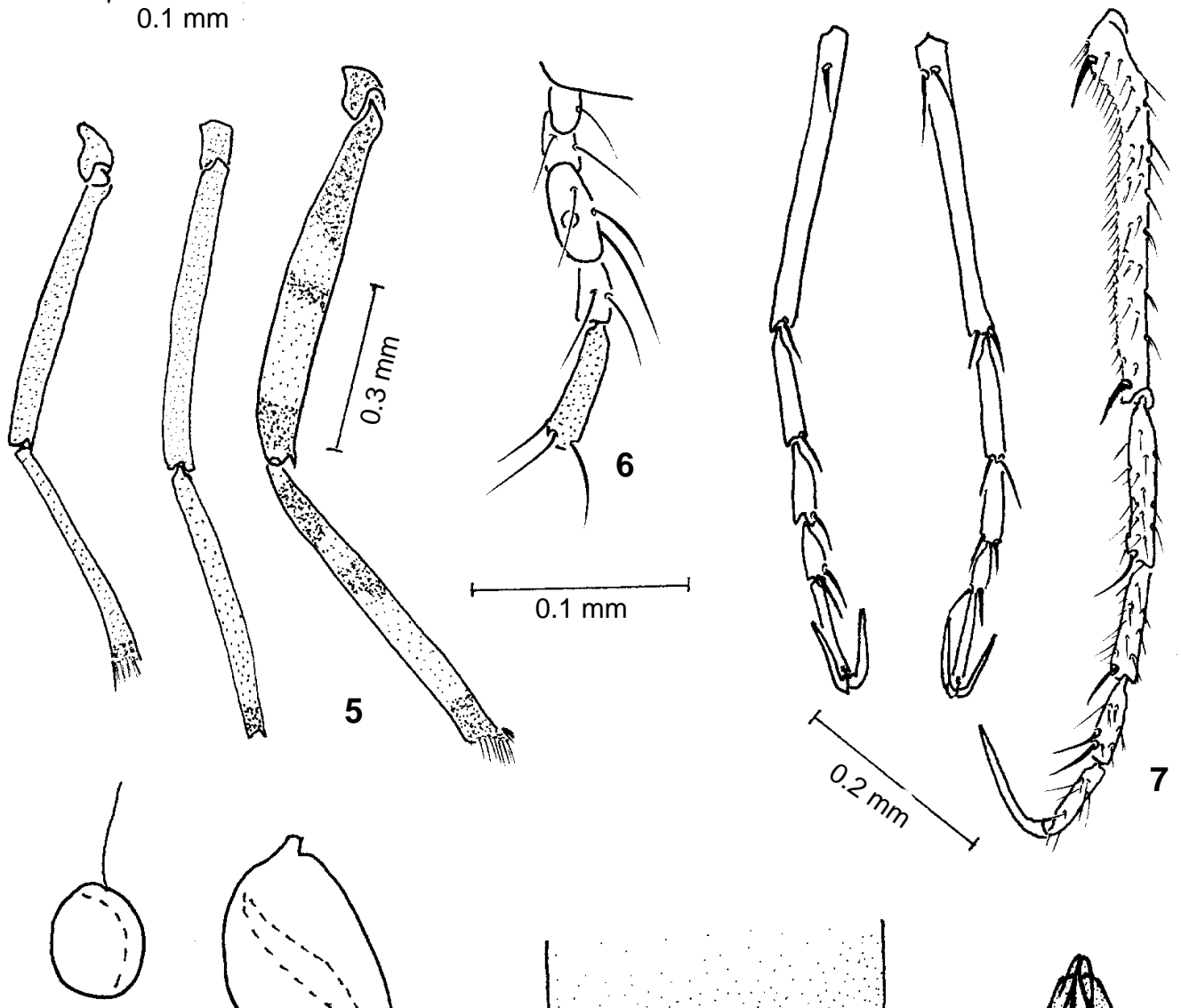

5
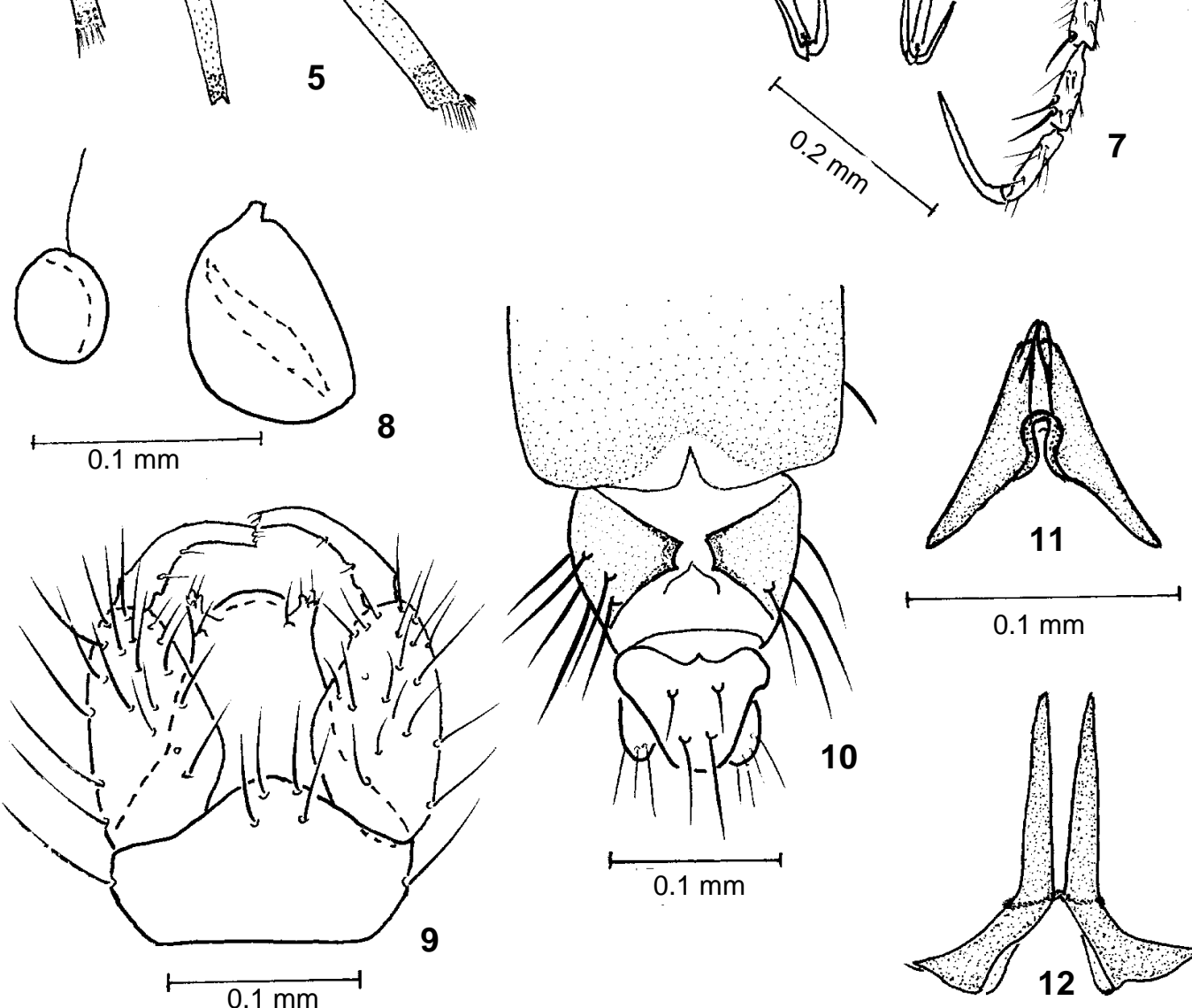

Monohelea maya sp.n. Fig. 3: eyes separation. Fig. 4: female antenna. Fig. 5: legs (left to right) fore, mid, hind. Fig. 6: female palpus. Fig. 7: tarsi (left to right) fore, mid, hind. Fig. 8: spermathecae. Fig. 9: male genitalia, aedeagus and parameres removed. Fig. 10: female abdomen. Fig. 11: aedeagus. Fig. 12: parameres 
Recently Delecolle and Rieb (1995) gave detailed redescriptions of the nearctic species $M$. floridensis Wirth \& Williams and M. macfiei Wirth and their new species M. grogani Delecolle \& Rieb, as well as the palearctic species, $M$. estonica Remm. The male genitalia of $M$. maya more closely resembles those of these species. However, M. maya can be separated from M. estonica and M. grogani by the absence of a median process on its gonocoxite. Also, M. estonica differs from M. maya by the different pattern of the leg pigmentation and by the gonostylus that is not so curved. M. maya differs from $M$. floridensis by the shape of the paramere which is simple, without subapical tooth. The new species differs from $M$. macfiei by the distribution of the dark spots on the wing. Finally, males of M. maya can also be separated from males of the above mentioned species by the shape of the stem of the paramere, which is straight.

\section{ACKNOWLEDGEMENTS}

To Drs WL Grogan and A Borkent for reviews of this paper. To Dr OP Forattini, Faculdade de Saúde Pública, Universidade de São Paulo, for the loan of material of Monohelea mayeri for study. To Genilton José Vieira, Laboratório de Produção e Tratamento de Imagem, for assistance with the wing photos.

\section{REFERENCES}

Borkent A, Wirth WW 1997. World species of biting midges (Diptera:Ceratopogonidae). Bull Am Mus Nat Hist 233: 1-257.

Delecolle JC, Rieb JP 1995. Redescription de Monohelea estonica Remm, 1965, de M. macfiei Wirth, 1953, et de M. floridensis Wirth \& Williams, 1964. Description d'une forme et d'une espèce nouvelle affines (Diptera, Ceratopogonidae). Nouv Revue Ent 12: 17-45.

Huerta HJ 1996. Los Ceratopogonidos Coletados por Alfonso Dampf en Chiapa, Mexico (Diptera: Ceratopogonidae), Thesis, Faculdad de Ciencias, Universidad Nacional Autonoma de Mexico, Mexico, D.F., 199 pp.

Lane J, Wirth WW 1964. The biting midge genus Monohelea Kieffer in the Neotropical Region (Diptera: Ceratopogonidae) Studia Ent 7: 209-236.

Ratanaworabhan NC, Wirth WW 1972. The biting midge genus Monohelea Kieffer in the Oriental Region (Diptera:Ceratopogonidae) Pacif Ins 14: 439-473.

Wirth WW, Grogan WL 1988. The Predaceous Midges of the World (Diptera: Ceratopogonidae; Tribe Ceratopogonini), Flora \& Fauna Handbook no. 4, EJ Brill, XV+160 pp.

Wirth WW, Williams RW 1964. New species and records of North American Monohelea (Diptera: Ceratopogonidae). Ann Ent Soc Amer 57: 302-310. 